\title{
A QUALITATIVE STUDY ON AIRFLOW CHARACTERISTICS ACROSS A WOODEN SLOTTED DOWN WINDOW PANEL FOR PASSIVE VENTILATION AND FAÇADE SHADING APPLICATION
}

\author{
NUR BAITUL IZATI RASLI1, NOR AZAM RAMLI*1, NOORFAZREENA MOHAMMAD \\ KAMARUDDIN $^{2}$, MOHD BADRUL SALLEH ${ }^{2}$, ABDELRAHMAN ISMAIL $^{2}$ AND MOHD \\ RODZI ISMAIL ${ }^{3}$
}

\begin{abstract}
${ }^{1}$ Environmental Assessment and Clean Air Research (EACAR), School of Civil Engineering, ${ }^{2}$ School of Aerospace Engineering, Engineering Campus, Universiti Sains Malaysia, 14300 Nibong Tebal, Penang, Malaysia. ${ }^{3}$ School of Housing Building and Planning, Universiti Sains Malaysia, 11800, Minden, Penang, Malaysia.
\end{abstract}

*Corresponding author: ceazam@usm.my

Submitted final draft: 1 November $2020 \quad$ Accepted: 25 December $2020 \quad$ http://doi.org/10.46754/jssm.2021.06.011

\begin{abstract}
Passive ventilation systems are typically used as alternatives to mechanical systems to facilitate airflow into and out of indoor spaces. Hence, this study is conducted to visualise the airflow characteristics of a wooden slotted down window panel at various airspeed (i.e. $0.5 \mathrm{~m} / \mathrm{s}, 1 \mathrm{~m} / \mathrm{s}, 2 \mathrm{~m} / \mathrm{s}, 3 \mathrm{~m} / \mathrm{s}$ and $5 \mathrm{~m} / \mathrm{s}$ ) using a smoke flow visualisation technique (i.e. smoke generator) performed in a closed-loop wind tunnel. Two $19201080 \mathrm{i}$ cameras were used to capture airflow characteristic images from the side and rear views, and front and back directions. The wooden slotted down window panel was proposed for installation in a building's wall for passive ventilation to facilitate optimum fresh outdoor airflow to replace the indoor air continuously. This study found that the highest airflow speed of $5 \mathrm{~m} / \mathrm{s}$, with turbulent airflow characteristics, could quickly fill an indoor space with air. The hygroscopic properties of wood used for the window panel model could also serve as an adaptive shading device for cooling effects indoors. Therefore, the wooden slotted down window panel might be used as a potential structure for passive ventilation and façade shading to enhance natural ventilation and provide satisfactory thermal comfort and indoor air quality.
\end{abstract}

Keywords: Air movement, indoor air quality, smoke flow visualisation, sustainability, thermal comfort.

\section{Introduction}

Malaysia is located in the equatorial region that experiences high temperatures and humidity (Jamaludin et al., 2015). According to Sembiring (2009), the sun shines at $23.4^{\circ}$ north latitude in the northern hemisphere in June, at $23.4^{\circ}$ south latitude in the southern hemisphere in December, and at zero degrees at the equator in March and September as illustrated in Figure 1. This phenomenon may lead to problems in indoor thermal comfort and moisture level (Hamimah et al., 2010). High solar radiation will increase indoor air temperatures in residential buildings in Malaysia, which may exceed the recommended limit of Malaysian Standard 1525:2007 of $23^{\circ} \mathrm{C}$ to $26^{\circ} \mathrm{C}$. Jamaludin et al. (2015) had recorded the highest indoor temperature of $32.6{ }^{\circ} \mathrm{C}$ within the urban microclimate in the capital of Kuala Lumpur.
Air-conditioning systems are installed to cool indoor environments for thermal comfort (Jamaludin et al., 2015). As such systems required a high amount of energy to operate, buildings consume approximately $50 \%$ of the total world energy (Pérez-Lombard et al., 2008), with the highest percentage identified in office buildings (Zhou \& Haghighat, 2009). Chong et al. (2015) reported that in 2011, commercial buildings in Malaysia are using $60 \%$ of their energy consumption for cooling purposes (Figure 2).

For residential buildings, Kubota et al. (2011) found that $65 \%$ of homeowners in Malaysia use air-conditioning at least six hours a day. Meanwhile, Rahman et al. (2017) indicated that fans are among the most popular electrical appliances in households. This finding implies the dependency of building occupants 


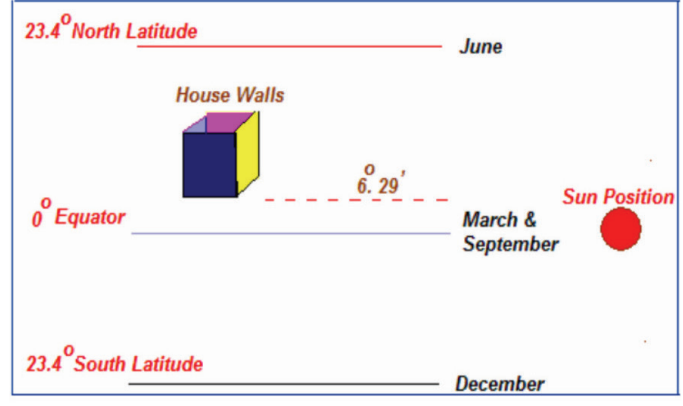

Figure 1: Sun positions in Malaysia in different months (Sembiring, 2009)

on mechanical ventilation for indoor thermal comfort. Thus, this subject requires focus on sustainability as it entails a high energy demand and cost to ensure that residential and commercial buildings are cool and comfortable (Jamaludin et al., 2015; Kubota \& Toe, 2015; Kassim et al., 2016; Cui et al., 2017; Laurini et al., 2017; Zaki et al., 2017). Furthermore, according to Da Graça and Linden (2016), the use of mechanical ventilation in most non-domestic buildings in developed countries has become increasingly prevalent, and less attention is being paid to natural methods. Moreover, Zaki et al. (2017) observed that the occupants' air-conditioning usage pattern is different in the hot and humid climate of Malaysia, where it is higher at night compared with daytime.

A natural ventilation system is highly profitable, as it is very efficient in curtailing electricity consumption and fossil fuel usage of buildings (Allocca et al., 2003; Gratia \& De Herde, 2007; Zhong et al., 2012). Moreover, such system may reduce energy costs, thereby enabling the creation of sustainable cities (Kassim et al., 2016). The efficiency of natural ventilation is generally influenced by the building shape, window designs, and configuration and wind turbulence (Mohammadmirzaei, 2018). According to Bangalee et al. (2014), outdoor fresh air may be drawn in to replace indoor air continuously through openings (i.e. vents, windows, doors and so on) naturally if there was a difference of temperature and pressure between the indoor and outdoor spaces. However, Zaki et al. (2018) found that aperture

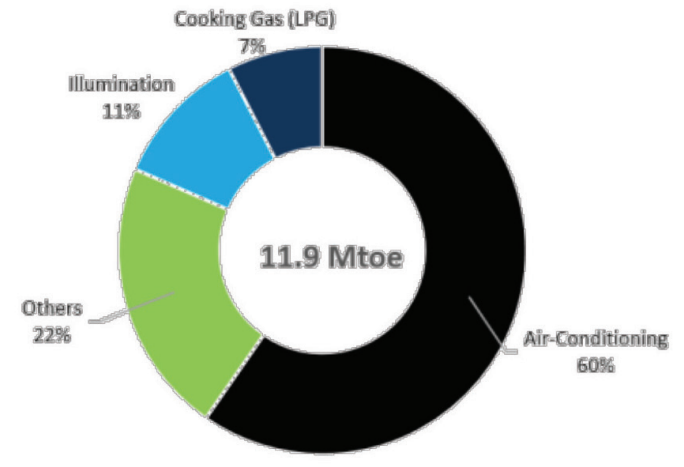

Figure 2: Breakdown of energy consumption of the commercial sector in Malaysia (Chong et al., 2015)

positions should be given consideration when designing buildings, as they may determine the effectiveness of wind-driven cross ventilation in urban areas.

In addition, in a hot and humid climate such as in Malaysia, numerous researchers have proposed potential natural passive cooling strategies in reducing indoor air temperature. Such strategies include natural ventilation physical passive design components (i.e. air well design, building façade, corridor and shading, blockage and partitions and ventilation openings), which concentrate airflow in or out of buildings (Siew et al., 2011). There are also mixed-mode ventilation proposals consisting of free-running ventilation with the aid of ceiling fans, air-conditioners and roof covers (Tuck et al., 2019 \& 2020). Kubota and Toe (2015) recommended the use of night ventilation, roof/ ceiling insulation, window/wall shading and courtyard/forced ventilation as passive cooling strategies. Furthermore, Rasli et al. (2019) showed that airflow can permeate into structures through pores on window panels by employing a smoke flow visualisation technique to determine the flow characteristics in a building model (Esfeh et al., 2012).

The present study seeks to develop and improve on the research by Rasli et al. (2019) by proposing a new wooden slotted down window panel design for passive ventilation and façade shading. Hence, this prototype model study, which represents actual airflow movement 
conditions from outdoor to indoor through openings in the building model (i.e. windows), is conducted in a closed-loop wind tunnel using smoke produced by a smoke generator to visualize airflow permeation through the window panel. The objective of this study is to see the airflow characteristics across the wooden slotted down window panel at various airflow speeds.

\section{Materials and Methods}

\section{Smoke Flow Visualisation Technique (i.e. Smoke Generator Technique)}

Testing was performed in a closed-loop wind tunnel in the Wind Tunnel Laboratory at the Science and Engineering Research Centre of Universiti Sains Malaysia using a a smoke generator at airflow speeds of $0.5 \mathrm{~m} / \mathrm{s}, 1.0 \mathrm{~m} / \mathrm{s}$, $2.0 \mathrm{~m} / \mathrm{s}, 3.0 \mathrm{~m} / \mathrm{s}$ and $5.0 \mathrm{~m} / \mathrm{s}$, with ventilation rates of $0.103 \mathrm{~m}^{3} / \mathrm{s}, 0.205 \mathrm{~m}^{3} / \mathrm{s}, 0.410 \mathrm{~m}^{3} / \mathrm{s}, 0.616$ $\mathrm{m}^{3} / \mathrm{s}$ and $1.026 \mathrm{~m}^{3} / \mathrm{s}$, respectively. The speeds were chosen because they represented the range of average wind speeds in the hot and humid climate of Malaysia (Lim et al., 2011; Makaremi et al., 2012; Bakar \& Gadi, 2016; Hanipah et al., 2016; Hanipah et al., 2017). Smoke was used to evaluate airflow characteristics of the wooden slotted down window panel model. The wind tunnel had a rectangular $1 \mathrm{~m} \times 0.80 \mathrm{~m} \times$ $1.80 \mathrm{~m}$ (width $\mathrm{x}$ height $\mathrm{x}$ length) testing section, with a contraction ratio of 10:1. The turbulence level of the closed-loop wind tunnel was $0.1 \%$, with flow speed reduced to $80 \mathrm{~m} / \mathrm{s}$. With the aid of a diffuser downstream in the testing section, an axial fan was used to drive airflow into the testing section. The wind tunnel control panel was used to control airflow speed, which was verified with a hot wire anemometer.

\section{Features of Wooden Slotted Down Window Panel Model}

A $1.00 \mathrm{~m} 0.80 \mathrm{~m}$ (width $\mathrm{x}$ height) wooden frame held the window panel in a vertical position in the middle of the testing section. The wooden slotted down window panel with a wooden frame is shown in Figure 3. The size of the wooden slotted down window panel was 0.36 $\mathrm{m} 0.57 \mathrm{~m}$ (width $\mathrm{x}$ height), and the panel was inserted at the centre of a clear $0.90 \mathrm{~m} 0.60 \mathrm{~m}$ (width $\mathrm{x}$ height) acrylic as shown in Figure 4. The wooden slotted down window panel model had an inclination angle of $75^{\circ}$ and 22 slots. The gap between each slot was $0.02 \mathrm{~m}$.

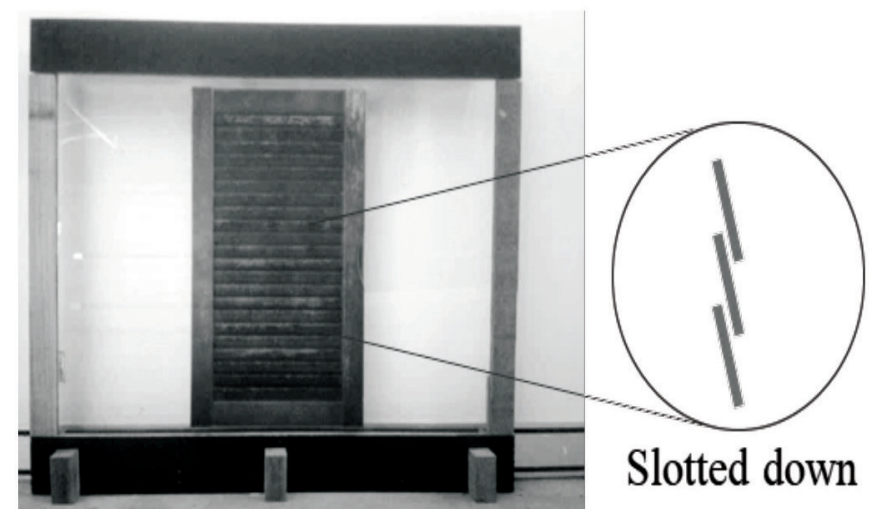

Figure 3: Wooden slotted down window panel with a wooden frame 


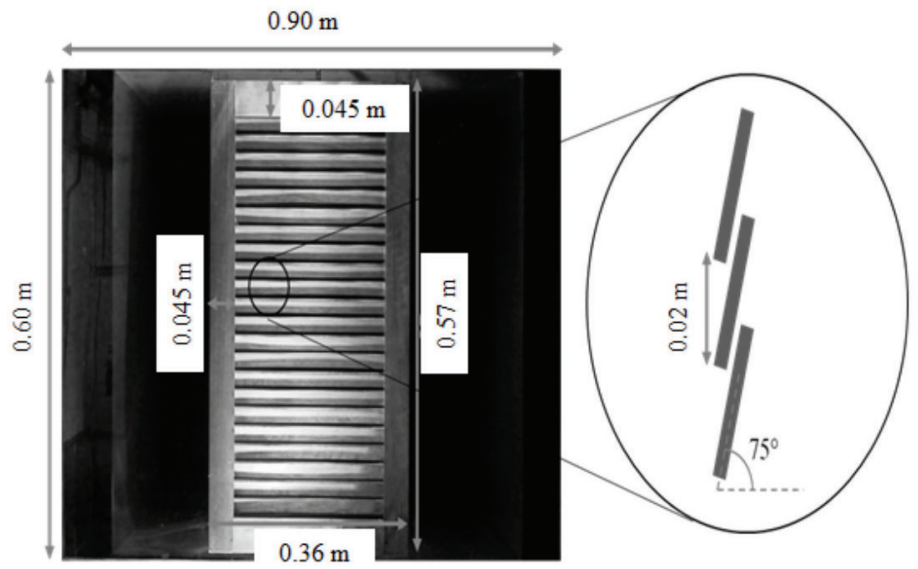

Figure 4: Dimensions of wooden slotted down window panel with an inclination angle of $75^{\circ}$ and 22 slots; gap between each slot was $0.02 \mathrm{~m}$

\section{Testing Procedure}

The wooden slotted down window panel setup with camera positions (i.e. side view, rear view, front shot and back shot) and the smoke generator is shown in Figure 5. A smoke rake was positioned vertically $0.25 \mathrm{~m}$ from the midsection of the wooden window panel, and the smoke generator setup was arranged at the top of the wind tunnel testing section. The distance of the slotted window panel with a wooden frame to the smoke rake was adjusted to $0.20 \mathrm{~m}, 0.25$ $\mathrm{m}$ and $0.30 \mathrm{~m}$ to capture the streamline of the smoke. At $0.20 \mathrm{~m}$, the streamline of the smoke could not be captured clearly, as it was too near the smoke source, whereas at $0.30 \mathrm{~m}$, the smoke began to spread. Therefore, the optimal distance was $0.25 \mathrm{~m}$, which contributed to the bestillustrated smoke streamline, which represented the airflow characteristics.

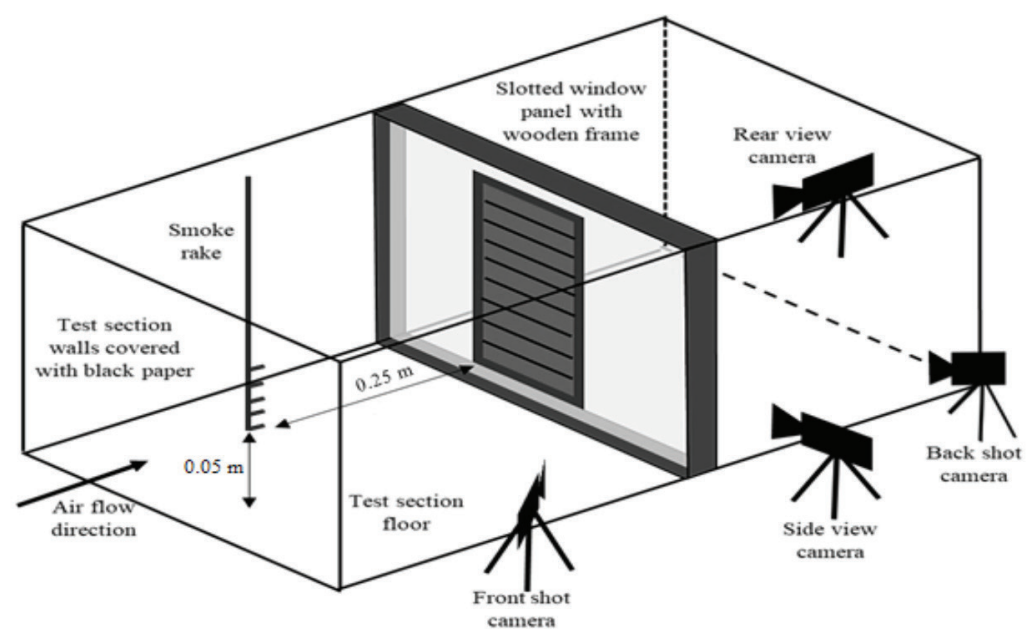

Figure 5: Schematic diagram of the wooden slotted down window panel setup with camera positions (i.e. side view, rear view, front shot and back shot) in this study that used the smoke generator technique in the wind tunnel testing section 


\section{Smoke Generator Technique}

A smoke generator i.e. SAFEX Fog Generator FOG 2010 (Dantec Dynamics, Skovlunde, Denmark) could continuously produce smoke particles. Figure 6 shows the smoke flow visualisation experimental setup using a smoke generator technique. The smoke generator was capable of generating smoke at a rate of approximately $10 \mathrm{~m}^{3} / \mathrm{sec}$. Smoke intensity was controlled using a handheld remote control. . Next, a rotary knob was scaled at No. 5 for a favourable amount of smoke, and a flexible delivery tube was used to connect the smoke generator. The smoke rake located in the testing section was used to generate smoke particles in the testing section. Smoke was released approximately 300 seconds from the smoke rake from each airflow speed section, and the best image of the smoke passing through the wooden slotted down window panel was chosen.

Next, the airflow movement characteristics were recorded using two Sony $1920 \quad 1080 \mathrm{i}$ cameras (Sony Corp, Tokyo, Japan). The cameras were mounted outside the centre (side view) and inside (rear view) the testing section. Testing was repeated with both cameras positioned outside at the front side and back side to capture airflow characteristic patterns from the front and back, respectively. A black piece of paper was utilised to minimise reflection inside the testing section and increase streamline clarity. To visually illuminate the smoke flow characteristic patterns released by the smoke rake, two white halogen light bulbs were placed at the top and bottom of the testing section.

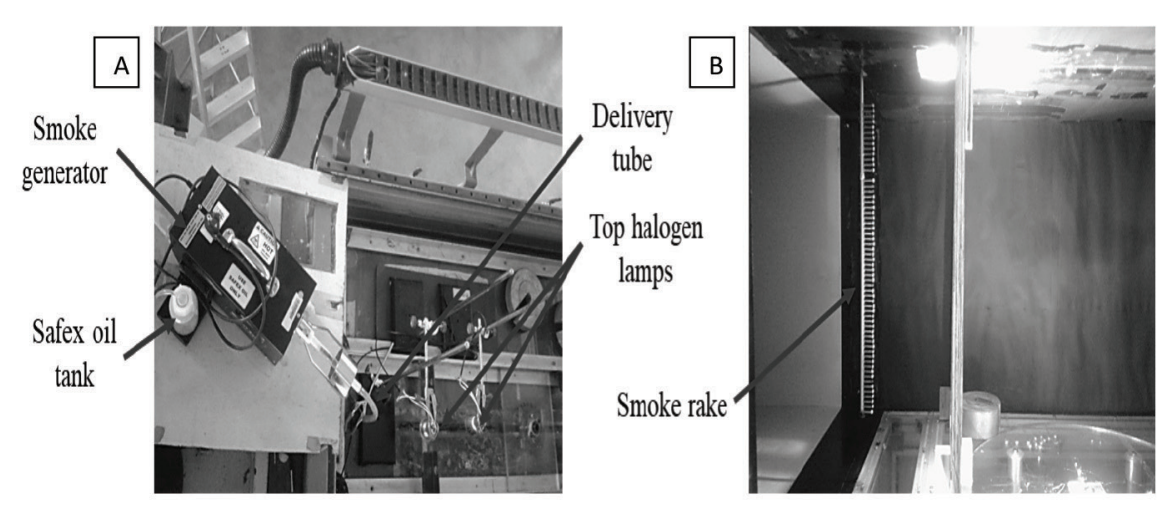

Figure 6: Smoke flow visualisation using a smoke generator technique; (a) instrument setup on the top of the wind tunnel testing section; (b) side view of wind tunnel with the wooden slotted down window panel model 


\section{Results and Discussion}

The vertical wooden slotted down window proposed in this study was used to facilitate optimum flow of fresh outdoor air towards an indoor space for passive ventilation to enhance thermal comfort and indoor air quality besides keeping out direct sunlight that may the temperature inside a room. Figures 7 to 11 show images of the wind tunnel testing results from the side view, rear view, front shot and back shot at five different airflow speeds (i.e. $0.5 \mathrm{~m} / \mathrm{s}, 1.0 \mathrm{~m} / \mathrm{s}, 2.0 \mathrm{~m} / \mathrm{s}, 3.0 \mathrm{~m} / \mathrm{s}$ and $5.0 \mathrm{~m} / \mathrm{s}$ ). The unrestricted airflow movement towards the indoor space was represented by the smoke streamline in the wind tunnel test.

The results showed that the smoke had permeated through the slotted down window panel at all airflow speeds and the airflow (smoke pattern) moved downwards as it passed through the window panel. Hence, fresh outdoor air could enter the room and replace the warm indoor air at low and high airflow speeds, thereby providing improved natural ventilation. Moreover, continuous natural ventilation at low and high airflow speeds was essential, as it could reduce certain indoor air contaminants present inside a house for years owing to dilution by outdoor air infiltration (Elodie et al., 2016). Rasli et al. (2019) also conducted wind tunnel research and proposed the use of the pores on a window panel to increase the maximum flow of fresh outdoor air towards an indoor space, which could potentially improve thermal comfort and indoor air quality. A wide natural ventilation area could offer improved indoor air quality and thermal comfort by decreasing temperatures in the space (Noman et al., 2016; Lei et al., 2017). Most importantly, the slotted down doors and windows need not be opened 24 hours a day, and air could still circulate continuously day and night.

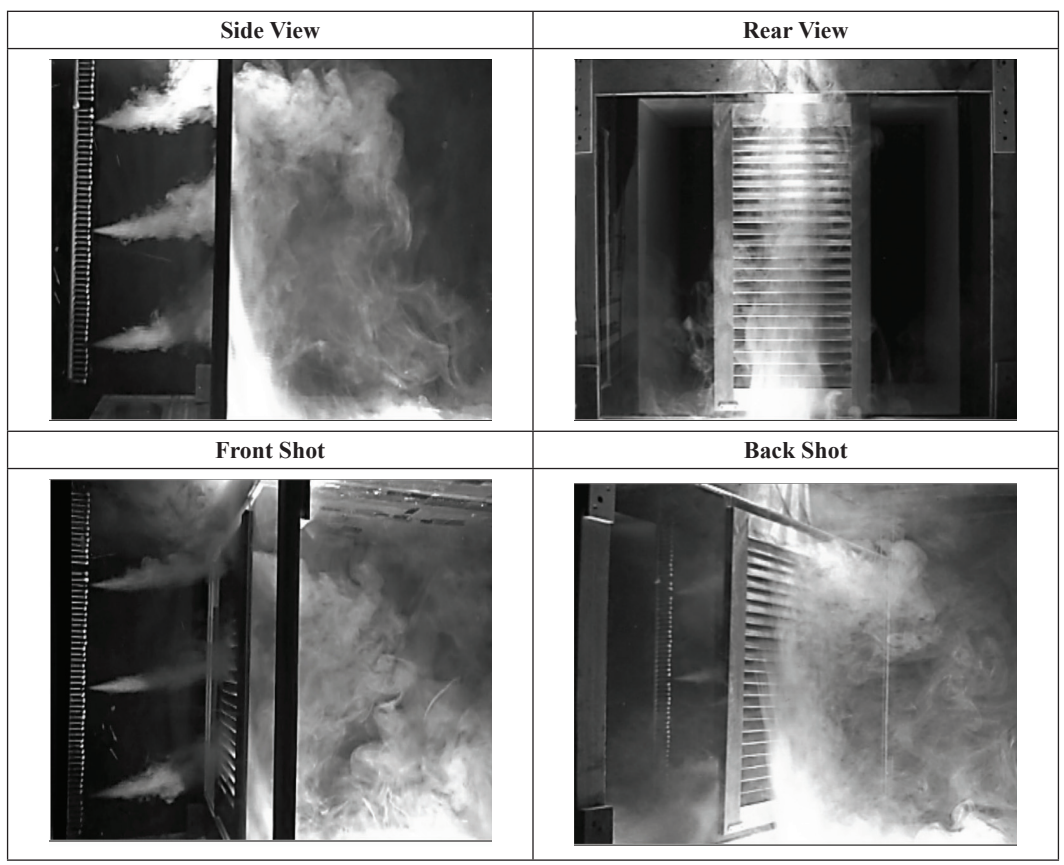

Figure 7: Smoke flowing across the wooden slotted down window panel at airflow speed of $0.5 \mathrm{~m} / \mathrm{s}$. At this low speed, the smoke may be seen lingering near the window as the airflow circulates across the room in a less turbulent and broad manner 


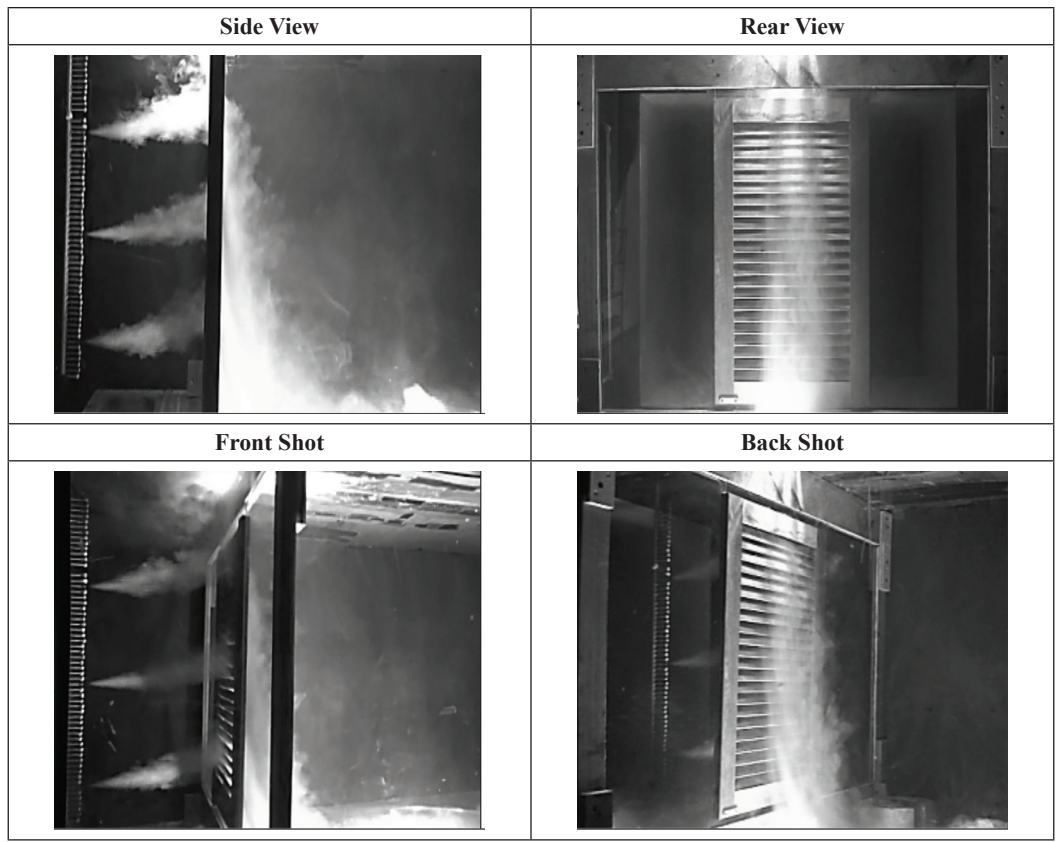

Figure 8: Smoke flowing downwards as it passes through the wooden slotted down window panel at an airflow speed of $1.0 \mathrm{~m} / \mathrm{s}$. At this speed, the airflow begins to move down the window, especially in the top part. But traces of smoke could still be seen lingering near the window and in the room

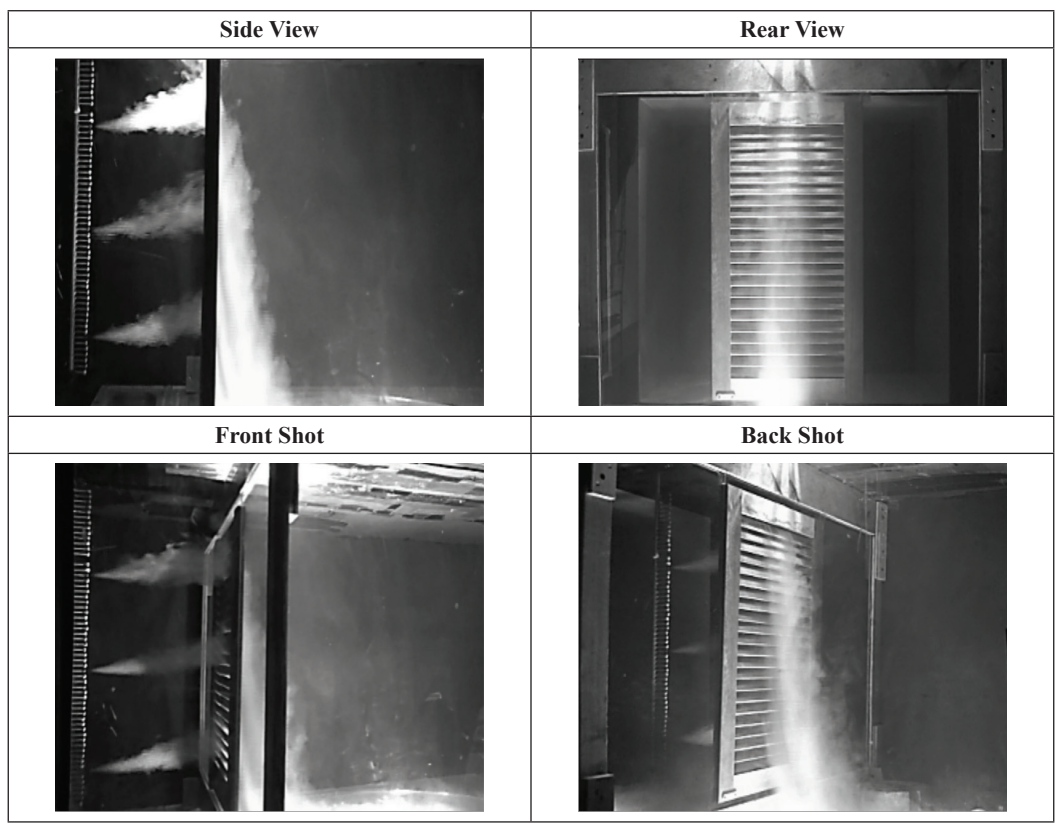

Figure 9: Smoke flowing downwards as it passes through the wooden slotted down window panel at an airflow speed of $2.0 \mathrm{~m} / \mathrm{s}$. At this intermediate speed, the airflow is clearly seen moving down and does not linger or spread at the top of the window 


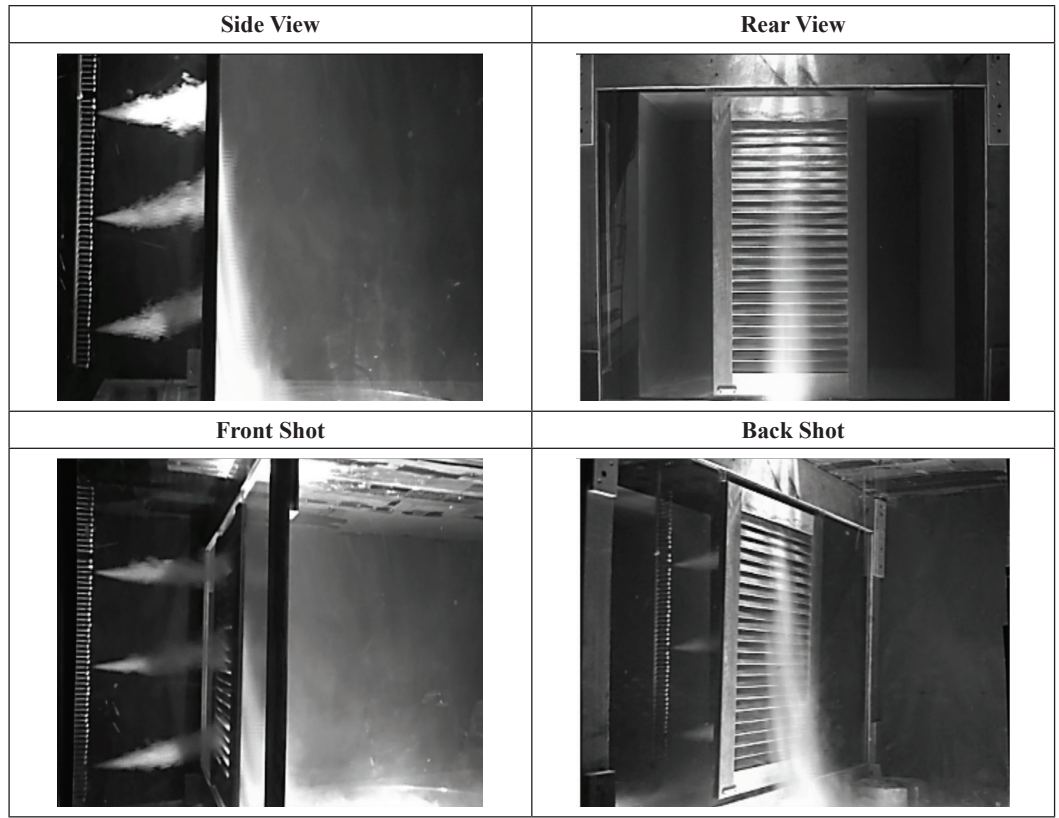

Figure 10: Smoke at the bottom of the room as it flows across the wooden slotted down window panel at an airflow speed of $3.0 \mathrm{~m} / \mathrm{s}$. At this high speed, airflow is more turbulent and begins concentrating at the bottom of the window

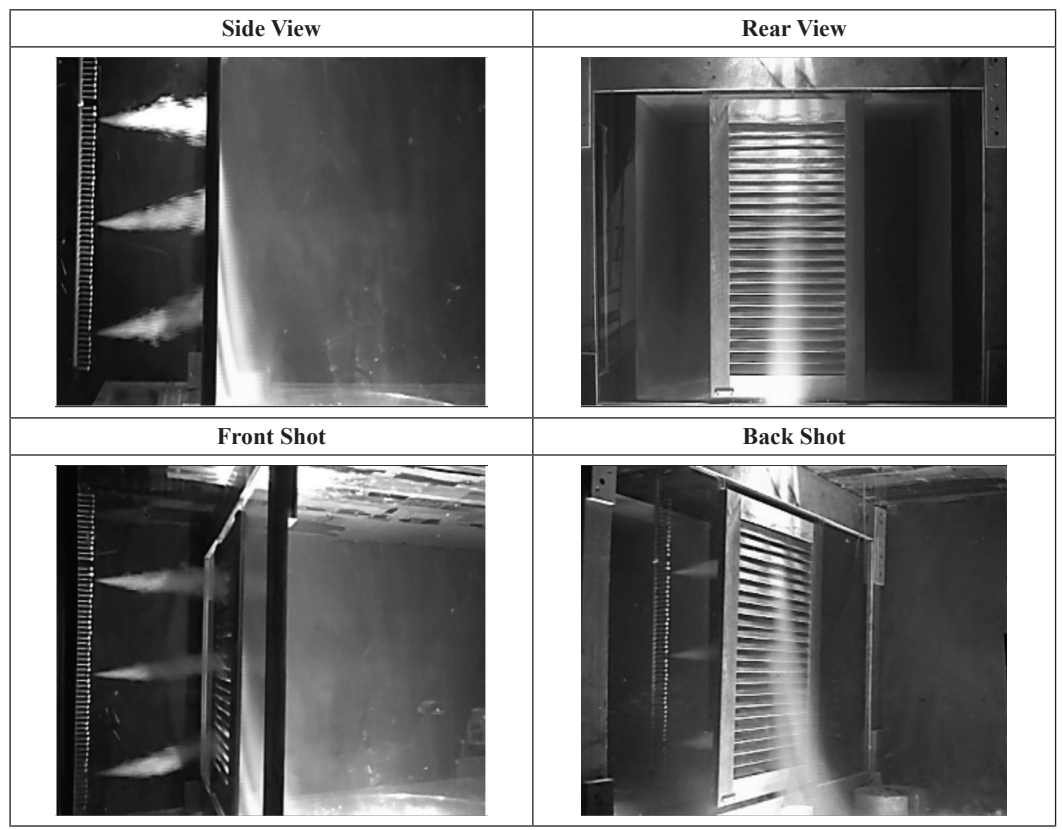

Figure 11: Smoke flowing to the bottom after passing the wooden slotted down window panel at an airflow speed of $5.0 \mathrm{~m} / \mathrm{s}$. At this highest speed, smoke is not seen in the room, indicating high mass flow rate and air density that hasten the air exchange process 
Besides, high airflow speeds permeating from the slotted down window panel could aid in regulating airflow characteristics in passive ventilation. At the highest airflow speed $(5 \mathrm{~m} / \mathrm{s})$, the air was observed to permeate the wooden slotted down window panel extremely fast. The airflow pattern at the leeward side tended to become more turbulent, straighter and smaller compared with that at lower airflow speeds (i.e. $0.5 \mathrm{~m} / \mathrm{s}, 1.0 \mathrm{~m} / \mathrm{s}, 2.0 \mathrm{~m} / \mathrm{s}$ and $3.0 \mathrm{~m} / \mathrm{s}$ ). Meanwhile, at the lowest speed $(0.5 \mathrm{~m} / \mathrm{s})$, airflow permeated the slotted down window panel at a slow rate, and the pattern at the leeward side was less turbulent, circulating and broad. Hence, these observations indicated that the higher the outdoor airflow speed, the more turbulent the airflow characteristics, with a higher mass flow rate and air density.

In real conditions, this phenomenon could result in the rapid mixing of indoor air and hasten the air exchange process simultaneously compared with low airflow speeds. Perhaps it could also lower indoor temperatures and reduce the contaminant level. High air density, with the aid of entrainment strength, could contribute to a high mass flow rate with elevated ambient pressure (Ji et al., 2018). Kosutova et al. (2019) found that the best air exchange efficiency could be obtained when louvred window openings were located at the centre of a building façade. Meanwhile, Aflaki et al. (2019) reported that a transom ventilation panel (space at the top of a door providing cross ventilation) could increase the mean air exchange rate by $27 \%$ and enhance the air exchange rate when the outdoor wind speed was less than $0.02 \mathrm{~m} / \mathrm{s}$. Furthermore, Chen et al. (2019) stated that natural ventilation could contribute to a higher ventilation rate compared with mechanical ventilation, with a natural ventilation reduction from $5 \%$ to $70 \%$ ), as tested in several cities in the United States.

The use of a slotted down window panel in buildings could introduce stack and cross ventilation. . Based on MS 1525:2014 (MS, 2014), stack ventilation could enhance airflow movement across spaces owing to air density differences. Warmed indoor air was a result of increased internal loads from people, equipment and lights in the room. Next, it would produce a vertical pressure gradient within the enclosed space. The warm air at the upper level would be discharged if there was an opening at the ceiling. Then, the cool outside air would enter the building through a low opening. Meanwhile, cross ventilation is caused by wind pressure differences. Air movement through cross ventilation could enhance airflow in a building through a wind-generated pressure drop. Hence, it could aid in achieving an improved indoor environment by providing satisfactory thermal comfort and indoor air quality.

In the present study, the incidence angle of the slotted down window panel was constant at $75^{\circ}$. In their wind tunnel test, $\mathrm{Bu}$ and Kato (2011) found that the wind incidence angle must be taken into consideration as wind incidence angle differences could contribute to turbulent inflow fluctuation differences. The airflow characteristics in the present study were turbulent at the leeward side in all airflow speeds, as the high resistance of large louvre slot angles (i.e. $75^{\circ}$ ) may aid in improving the mixing of air to reduce temperatures and indoor air contaminants. This finding was in line with the findings of Chandrashekaran (2010), considering the results of the slotted louvre window. A $45^{\circ}$ louvre slot had a higher pressure difference than a slot with a smaller angle at a given outdoor airflow speed in wind tunnel testing, which enabled improved mixing affecting internal velocities. Airflow would become turbulent as the louvre angle increased (i.e. $30^{\circ}$ and $45^{\circ}$ ) because it facilitated the rapid mixing of air at velocities within ASHRAE thermal comfort standards compared with transitional and laminar flows.

Moreover, wood was selected as material for the window panels for façade shading because it could aid in creating a cooling effect in indoor environments. A louvre window panel would allow air to pass indoors and block direct sunlight if an opaque material was utilised (Chandrashekaran, 2010). Moreover, it could also aid in the cooling effect by absorbing significant amounts of moisture from the 
atmosphere during humid nighttime hours, with the evaporation process occurring the next day (Lokko \& Rempel, 2018; Vailati et al., 2018). Furthermore, the hygroscopic properties of wood as an adaptive sunlight shading device could reduce energy costs, improve energy efficiency and enhance indoor comfort in buildings (Hammad \& Abu-Hijleh, 2010; Palmero-Marrero \& Oliveira, 2010; Vailati et al., 2018; El-Dabaa et al., 2020).

\section{Conclusion}

The application of natural ventilation could provide satisfactory indoor thermal comfort and air quality. The major contributions of this study were as follows:

1) Outdoor air could continuously replace indoor air as the smoke permeated the slotted down window panel at all tested airflow speeds.

2) High airflow speeds would promote turbulent characteristics and high mass airflow rates, which could contribute to high air exchange rates indoors compared with lower speeds.

3) The hygroscopic properties of wood used as the material for the window panel model could serve as an adaptive shading device for cooling effects indoors.

Therefore, installing a wooden slotted down window panel in a building wall could potentially solve thermal comfort issues, thereby achieving sustainable building goals.

\section{Acknowledgements}

The study was supported by Universiti Sains Malaysia through the university's Bridging Grant (304/PAWAM/6316537).

\section{References}

Aflaki, A., Hirbodi, K., Mahyuddin, N., Yaghoubi, M., \& Esfandiari, M. (2019). Improving the air change rate in high-rise buildings through a transom ventilation panel: A case study. Building and Environment, 147, 35-49.

Allocca, C., Chen, Q., \& Glicksman, L. R. (2003). Design analysis of single-sided natural ventilation. Energy and Buildings, 35(8), 785-795.

Bakar, A. A. \& Gadi, M. B. (2016). Urban outdoor thermal comfort of the hot-humid region. In MATEC Web of Conferences, EDP Sciences, 66, 00084.

Bangalee, M. Z. I., Miau, J. J., Lin, S. Y., \& Ferdows, M. (2014). Effects of lateral window position and wind direction on wind-driven natural cross ventilation of a building: A computational approach, Journal of Computational Engineering, 2014, 1-15.

Bu, Z., \& Kato, S. (2011). Wind-induced ventilation performances and airflow characteristics in an areaway-attached basement with a single-sided opening. Building and Environment, 46(4), 911-921.

Chandrashekaran, D. (2010). Air flow through louvered openings: Effect of louver slats on air movement inside a space. University of Southern California.

Chen, J., Brager, G.S., Augenbroe, G., \& Song, X. (2019). Impact of outdoor air quality on the natural ventilation usage of commercial buildings in the US. Applied Energy, 235, 673-684.

Chong, C., Ni, W., Ma, L., Liu, P. \& Li, Z. (2015). The use of energy in Malaysia: Tracing energy flows from primary source to end use. Energies, 8, 2828-2866.

Cui, X., Mohan, B., Islam, M. R., Chou, S. K., \& Chua, K. J. (2017). Energy-saving potential of an air treatment system for improved building indoor air quality in Singapore. Energy Procedia, 143, 283-288.

da Graça, G. C., \& Linden, P. (2016). Ten questions about natural ventilation of non-domestic buildings. Building and Environment, 107, 263-273. 
El-Dabaa, R., Abdelmohsen, S., \& Mansour, Y. (2020). Programmable passive actuation for adaptive building façade design using hygroscopic properties of wood. Wood Material Science \& Engineering, 1-14.

Elodie, M. G., Fabrice, A., Johnny, G., Martine, B., Marie, J. T., Corinne, M., \& Marc, C. (2016). Seasonal fate and gas/particle partitioning of semi-volatile organic compounds in indoor and outdoor air. Atmospheric Environment, 147, 423-433.

Esfeh, M. K., Dehghan, A. A., Manshadi, M. D., \& Mohagheghian, S. (2012). Visualised flow characteristic around and inside of onesided wind-catchers. Energy and Buildings, 55, 545-552.

Gratia, E., \& De Herde, A. (2007). Guidelines for improving natural daytime ventilation in an office building with a double-skin facade. Solar energy, 81(4), 435-448.

Hammad, F., \& Abu-Hijleh, B. (2010). The energy savings potential of using dynamic external louvers in an office building. Energy and Buildings, 42(10), 1888-1895.

Hanipah, M. H., Abdullah, A. H., Che Sidek, N. A., Yunus, R., Nagapan, S., Yasin, M. N., \& Muhammad Yazid, M. N. A. W. (2017). Wind characteristics and outdoor thermal comfort assessment in East Malaysia. Pertanika Journal of Science \& Technology, 25, 63-72.

Hanipah, M. H., Sidik, N. A. C., Yunus, R., Yasin, M. N. A., \& Yazid, M. N. A. W. M. (2016). Assessment of outdoor thermal comfort and wind characteristics at three different locations in Peninsular Malaysia. In MATEC Web of Conferences, EDP Sciences, 47, 04005.

Jamaludin, N., Mohammed, N. I., Khamidi, M. F., \& Wahab, S. N. A. (2015). Thermal comfort of residential building in Malaysia at different micro-climates. Procedia-Social and Behavioral Sciences, 170, 613-623.

Ji, J., Guo, F., Gao, Z., \& Zhu, J. (2018). Effects of ambient pressure on transport characteristics of thermal-driven smoke flow in a tunnel. International Journal of Thermal Sciences, 125, 210-217.

Kasim, N. F. M., Zaki, S. A., Ali, M. S. M., Ikegaya, N., \& Razak, A. A. (2016). Computational study on the influence of different opening position on wind-induced natural ventilation in urban building of cubical array. Procedia Engineering, 169, 256-263.

Kosutova, K., van Hooff, T., Vanderwel, C., Blocken, B., \& Hensen, J. (2019). Crossventilation in a generic isolated building equipped with louvers: Wind-tunnel experiments and CFD simulations. Building and Environment, 154, 263-280.

Kubota, T., Hooi, S., \& Remac, D. C. T. (2011). Energy consumption and air-conditioning usage in residentials buildings in Malaysia. Journal of International Development and Cooperation, 17, 61-69.

Kubota, T., \& Toe, D. H. C. (2015). Application of passive cooling techniques in vernacular houses to modern urban houses: A case study of Malaysia. Procedia-social and Behavioral Sciences, 179, 29-39.

Laurini, E., Taballione, A., Rotilio, M., \& De Berardinis, P. (2017). Analysis and exploitation of the stack ventilation in the historic context of high architectural, environmental and landscape value. Energy Procedia, 133, 268-280.

Lei, Z., Liu, C., Wang, L., \& Li, N. (2017). Effect of natural ventilation on indoor air quality and thermal comfort in dormitory during winter. Building and Environment, 125, 240-247.

Lim, C., Saadatian, O., Suleiman, M., Mat, S. O. H. I. F., \& Sopian, K. (2011). Performance of wind-induced natural ventilation tower in hot and humid climatic conditions. In The 9th WSEAS International Conference on Environment, Ecosystems and Development (EED'11), Montreux Switzerland, 125-131. 
Mae-ling, L., \& Rempel, A. (2018). Intrinsic evaporative cooling with natural ventilation and shading for adaptive thermal comfort in tropical buildings. Proceedings of 7th International Building Physics Conference, Syracuse, NY, USA, 23-26 September 2018, 1413-1418, https://surface.syr.edu/cgi/viewcontent. cgi? article $=1288 \&$ context $=\mathrm{ibpc}$

Makaremi, N., Salleh, E., Jaafar, M. Z., \& GhaffarianHoseini, A. (2012). Thermal comfort conditions of shaded outdoor spaces in hot and humid climate of Malaysia. Building and Environment, 48, 7-14.

Mohammadmirzaei, M. (2018). Numerical studies of turbulence effects in cross-flow ventilation. (4948) [Master's thesis, San José State University].

MS. (2014). Malaysian Standard. MS 1525:2014. Energy efficiency and use of renewable energy for non-residential buildings - Code of practice (Second revision). Department of Standards Malaysia. Malaysia.

Noman, F. G., Kamsah, N., \& Kamar, H. M. (2016). Improvement of thermal comfort inside a mosque building. Jurnal Teknologi, 78(5-8), 9-18.

Palmero-Marrero, A. I., \& Oliveira, A. C. (2010). Effect of louver shading devices on building energy requirements. Applied Energy, 87(6), 2040-2049.

Pérez-Lombard, L., Ortiz, J., \& Pout, C. (2008). A review on buildings energy consumption information. Energy and Buildings, 40(3), 394-398.

Rahman, K. A., Leman, A. M., Mubin, M. F., Yusof, M. Z. M, Hariri, A., \& Saleh, M. N. M. (2017). Energy consumption analysis based on energy efficiency approach: A case of suburban area. In MATEC Web of Conferences, EDP Sciences, 87, 02003.

Rasli, N. B. I., Ramli, N. A., Ismail, M. R., Faizah, N., Yusof, F. M., Shith, S., Kamaruddin, N. M., Salleh, M. B., \& Nazir, A. U. M. (2019). Smoke flow visualisation testing on window panel at various wind speed and pores: a wind tunnel study. Journal of Sustainability Science and Management, 14(6), 66-79.

Sembiring, M. (2009). Prediction of house walls temperatures subjected to solar energy in Northern Malaysia. In Proceedings of International Conference on Applications and Design in Mechanical Engineering (ICADME), 11 - 13 October 2009, Batu Ferringhi, Penang, MALAYSIA, 2009.

Siew, C. C., Che-Ani, A. I., Tawil, N. M., Abdullah, N. A. G., \& Mohd-Tahir, M. (2011). Classification of natural ventilation strategies in optimising energy consumption in Malaysian office buildings. Procedia Engineering, 20, 363-371.

Tuck, N. W., Zaki, S. A., Hagishima, A., Rijal, H. B., \& Yakub, F. (2020). Affordable retrofitting methods to achieve thermal comfort for a terrace house in Malaysia with a hot-humid climate. Energy and Buildings, 223, 1-16.

Tuck, N. W., Zaki, S. A., Hagishima, A., Rijal, H. B., Zakaria, M. A., \& Yakub, F. (2019). Effectiveness of free running passive cooling strategies for indoor thermal environments: Example from a two-storey corner terrace house in Malaysia. Building and Environment, 160, 1-13.

Vailati, C., Bachtiar, E., Hass, P., Burgert, I., \& Rüggeberg, M. (2018). An autonomous shading system based on coupled wood bilayer elements. Energy and Buildings, 158, 1013-1022.

Zaki, S. A., Damiati, S. A., Rijal, H. B., Hagishima, A., \& Abd Razak, A. (2017). Adaptive thermal comfort in university classrooms in Malaysia and Japan. Building and Environment, 122, 294-306.

Zaki, S. A., Hagishima, A., Fukami, R., \& Fadhilah, N. (2017). Development of a model for generating air-conditioner operation schedules in Malaysia. Building and Environment, 122, 354-362. 
Zaki, S. A., Kasim, N. F. M., Ikegaya, N., Zhong, K., Yang, X., Feng, W., \& Kang, Y. Hagishima, A., \& Ali, M. S. M. (2018). Numerical simulation on wind-driven cross ventilation in square arrays of urban buildings with different opening positions. Journal of Advanced Research in Fluid Mechanics and Thermal Sciences, 49(2), 101-114. (2012). Pollutant dilution in displacement natural ventilation rooms with inner sources. Building and Environment, 56, 108-117.

Zhou, L., \& Haghighat, F. (2009). Optimisation of ventilation system design and operation in office environment, Part I: Methodology. Building and Environment, 44(4), 651-656. 